\title{
6. Winning the right to information in India: is knowledge power?
}

\author{
AMITA BAVISKAR ${ }^{1}$
}

All over India, along dusty rural roads and city streets, one can now see signboards in the local language announcing ongoing construction works. Whether repairing a road, building a school or bridge, or digging a check-dam, the government prominently displays basic information about the work undertaken. The signs make public the purpose and technical specifications of a project, and its cost, source of funding, executing agency and date of commencement. They declare the government's commitment to transparency in public expenditure, acknowledging a demand that has been vigorously voiced by various social groups in India in the last decade, latterly under the rubric of the National Campaign for the Right to Information. Through the signboards, a major achievement in the struggle for greater accountability in governance is writ large across the Indian landscape.

Mandated by the government as a response to public pressure, the signboards would be meaningless if the process of mobilization that led to them was not sustained. In the past, these signs would merely have served a cosmetic purpose. Even the literate few who could understand them would have found it almost impossible to negotiate their way through the labyrinths of government procedure to verify whether a project met its stated parameters. Take roadworks, for instance. Each year, a municipality spends millions of rupees on road repairs, usually subcontracting to private firms which often corner jobs by bribing the appropriate municipal officials to reject more competitive bids. Once their bid has been chosen, these firms short-change the public by using substandard materials and by cutting corners in the work process. Another round of bribes at the time of inspection ensures that the work is approved and their payments cleared. Confronted with roads that become potholed barely a month after repair, most citizens can do little to challenge the rampant corruption in public works.

This dismal state of affairs received a major jolt when citizens' groups in various parts of India began using their right to information (RTI) to inspect government documents. Upon payment of a nominal fee and 
photocopying charges, any citizen can now ask for specific information and the competent government authority is required to respond within a short period. If information is not provided, or if it is inaccurate or incomplete, citizens can complain to a Public Grievance Commissioner. If an officer is found delaying or withholding information or supplying wrong information, they can be fined a fixed amount for each day of delay.

In the example of road repairs, how did examining the public record help? Comparing government papers with physical inspections of the work and building materials with their official specifications showed precisely where the records had been fudged and by whom. Not only were groups enabled to demand that incompetent and corrupt officials be prosecuted and collaborating firms blacklisted, but their vigilance and continued public scrutiny ensured that future projects were less likely to be undermined by corrupt practices. As a result of these efforts, greater probity and efficacy in public works are much more likely.

The National Campaign for People's Right to Information (NCPRI) was formally launched in 1996 at a gathering of more than a hundred activist organizations. Campaign leaders described their goals as transparency in public life, empowerment of people, deepening of democracy, and fighting corruption, and their primary focus was to campaign for a national law on the right to information. In the same year, the NCPRI and the Press Council of India sent the first draft of such a law to the government for consideration. Since then, nine out of twenty-eight Indian states have enacted legislation to grant citizens RTI, and on 12 October 2005, the national government, led by the Congress Party, made operational a national Right to Information Act, a major milestone in the NCPRI's ongoing struggle. As required by the Act, all government departments and public sector organizations are currently putting together the infrastructure needed to meet public demands for information. This entails appointing Public Information Officers and training personnel to answer queries. Such a flurry of bureaucratic activity in response to a new law is unusual. How was such a radical piece of legislation passed and notified? ${ }^{2}$

The demand for RTI grew from tiny sporadic initiatives dispersed across the country to a concerted campaign. The forging of horizontal links was matched by the leap in vertical reach, from targeting local governments and small projects to securing legislative action at the highest levels of the state. Translating legislation into practice seems much more likely with the strongly mobilized grassroots organizational network of the NCPRI. 
The recent successes of the NCPRI are all the more impressive because its constituent organizations belong to that most marginal political group - people's organizations. Neither NGOs that draw on donor funding, nor formal political parties, some of these groups achieve a prominence out of proportion to the numbers they represent, especially when they address issues of national development and the environment, but the majority labour on in relative obscurity. How were these small localized groups able to sustain a long-term campaign that resulted in opening up the public sphere, enabling popular participation that made the government more accountable to ordinary citizens? What strategies of networking did they use to expand and consolidate their sphere of influence? How were they able to win over neutral groups and neutralize hostile ones?

There are also other intriguing aspects to the NCPRI. In the early 1990s, no observer of the social movement scene in India would have identified RTI as a significant political issue. The top contender would have been the campaign against displacement by development projects, spearheaded by the movement against the dams on the river Narmada, which focused its critique on the pattern of development that displaced poor communities by usurping their land and natural resources. Within this campaign, the question of citizens' RTI did crop up repeatedly as social movements sought greater information on government projects. Yet, while the demand for greater public accountability was an intrinsic element of the social movements of the 1980s and early 1990s, they did not directly or explicitly focus on the RTI. What has enabled the current campaign to act in a concerted fashion? How does it draw on the networks and political analyses created by the National Alliance of People's Movements, started up by the Narmada activists in the early 1990s? In what ways do its strategies diverge from those of previous campaigns?

Another curious aspect of the success of the NCPRI is the fact that it has occurred during a period when successive governments have firmly established the Indian economy on the path of economic liberalization. Neoliberal policies have resulted in the shrinking of poor people's access to basic subsistence and in the denial of government goods and services to them. Does this context make the RTI campaign an anomaly? Should it be interpreted as a democratic sop, meant to create political legitimacy even as the economic ground is being cut from under people's feet? After all, what use is information if you cannot feed yourself? Left radicals may dismiss RTI as a liberal anodyne, and accuse the government of cold-blooded cynicism: if they don't have bread, let them eat paper. What 